\title{
THE PRESIDENT'S CONSTITUTIONAL AUTHORITY TO CONDUCT MILITARY OPERATIONS AGAINST TERRORIST ORGANIZATIONS AND THE NATIONS THAT HARBOR OR SUPPORT THEM
}

\author{
ROBERT J. DELAHUNTY* AND JOHN C. YOO*
}

The terrorist attacks on the United States on September 11, 2001 raised important questions concerning the President's authority to take military action in response. Although Congress acted promptly to pass legislation authorizing the President to take military action against the terrorists and those linked to them, ${ }^{1}$ we shall argue the President has broad constitutional power, even without such legislation, to deploy military force to retaliate against those implicated in the September 11 attacks. Congress acknowledged this inherent executive power in its recent legislation, as it had earlier in the War Powers Resolution (the "WPR"). ${ }^{2}$ Further, we shall argue, the President had the innate power not only to retaliate against any person, organization, or state suspected of involvement in terrorist attacks on the United States, but also against foreign states suspected of harboring or supporting such organizations. Finally, we shall contend that the President's constitutional authority to deploy military force against terrorists and the states that harbor or support them includes both the power to respond to past attacks and the power to act preemptively against future ones.

\footnotetext{
* Deputy General Counsel, Office of Homeland Security; Special Counsel, Office of Legal Counsel, United States Department of Justice.

** Deputy Assistant Attorney General, Office of Legal Counsel, United States Department of Justice; Professor of Law, University of California at Berkeley School of Law (Boalt Hall) (on leave). Our views are our own and do not represent those of the Department of Justice.

1. Joint Resolution to Authorize the Use of United States Armed Forces Against Those Responsible for the Recent Attacks Against the United States, Pub. L. No. 107-40, 115 Stat. 224 (2001).
}

2. Pub. L. No. 93-148, 87 Stat. 555 (1973) (codified at 50 U.S.C. $\$ \S 1541-48$ (1994)). 
Our analysis falls into four parts. First, we examine the constitutional text and structure. We conclude that the Constitution vests the President with the plenary authority, as Commander in Chief and the sole organ of the nation in its foreign relations, to use military force abroad, especially in response to grave national emergencies created by sudden, unforeseen attacks on the people and territory of the United States. Second, we confirm that conclusion by reviewing executive and judicial statements and decisions interpreting the President's constitutional powers. Third, we analyze the relevant historical precedent, which supports the argument for Presidential authority in these matters. Finally, we discuss congressional enactments that acknowledge the President's full authority to use force both to respond to the September 11 attacks on the United States and to deter future strikes of that nature.

\section{CONSTITUTIONAL AUTHORITY}

The President's constitutional power to defend the United States and its citizens must be understood in the context of the Founders' express intention to create a federal government "clothed with all the powers requisite to [the] complete execution of its trust." 3 Foremost among the objectives committed to that trust is the the nation's security. ${ }^{4}$ As Hamilton explained in arguing for the Constitution's adoption, because:

the circumstances which may affect the public safety are [not] reducible within certain determinate limits, ... it must be admitted, as a necessary consequence that there can be no limitation of that authority which is to provide for the defense and protection of the community in any matter essential to its efficacy.

3. THE FEDERALIST No. 23, at 121-22 (Alexander Hamilton) (Clinton Rossiter ed., 1961).

4. Youngstown Sheet \& Tube Co. v. Sawyer, 343 U.S. 579, 662 (1952) (Clark, J., concurring in judgment) ("As Lincoln aptly said, '[is] it possible to lose the nation and yet preserve the Constitution?'") (quoting Letter from Abraham Lincoln to A.G. Hodges (Apr. 4, 1864), in 10 COMPLETE WORKS OF ABRAHAM LINCOLN 65, 66 (John G. Nicolay \& John Hay eds., 1894)).

5. THE FEDERALIST NO. 23, supra note 3, at 122; see also THE FEDERALIST NO. 34, at 175 (Alexander Hamilton) (Clinton Rossiter ed., 1961) (stating that the federal government should possess "an indefinite power of providing for emergencies as they might arise"); THE FEDERALIST NO. 41, at 224 (James Madison) (Clinton 
"It is 'obvious and unarguable' that no governmental interest is more compelling than the security of the Nation." 6 Within the limits that the Constitution itself imposes, the scope and distribution of the powers to protect national security must be construed to authorize the most efficacious defense of the nation and its interests in accordance "with the realistic purposes of the entire instrument." ${ }^{\prime 7}$ Nor is the authority to protect national security limited to actions necessary for "victories in the field." ${ }^{\prime 8}$ The authority over national security "carries with it the inherent power to guard against the immediate renewal of the conflict."

\section{A. Constitutional Text}

The text, structure, and history of the Constitution establish that the Founders entrusted the President with the primary responsibility, and therefore the power, to use military force in situations of emergency. Article II, Section 2 states that the "President shall be Commander in Chief of the Army and Navy of the United States, and of the Militia of the several States, when called into the actual Service of the United States. ${ }^{10} \mathrm{He}$ is further vested with all of "the executive Power" and the duty to execute the laws. These powers give the President broad constitutional authority to use military force in

Rossiter ed., 1961) ('Security against foreign danger is one of the primitive objects of civil society. ... The powers requisite for attaining it must be confided to the federal councils."). Many Supreme Court opinions echo Hamilton's argument that the Constitution presupposes the indefinite and unpredictable nature of the "the circumstances which may affect the public safety," and that the federal government's powers are correspondingly broad. See, e.g., Dames \& Moore v. Regan, 453 U.S. 654, 662 (1981) (noting that the President "exercis[es] the executive authority in a world that presents each day some new challenge with which he must deal"); Hamilton v. Regents, 293 U.S. 245, 264 (1934) (stating that the federal government's war powers are "well-nigh limitless" in extent); Stewart v. Kahn, 78 U.S. (11 Wall.) 493, 506 (1870) ("The measures to be taken in carrying on war... are not defined [in the Constitution]. The decision of all such questions rests wholly in the discretion of those to whom the substantial powers involved are confided by the Constitution."); Miller v. United States, 78 U.S. (11 Wall.) 268, 305 (1870) ("The Constitution confers upon Congress expressly power to declare war, grant letters of marque and reprisal, and make rules respecting captures on land and water. Upon the exercise of these powers no restrictions are imposed. Of course the power to declare war involves the power to prosecute it by all means and in any manner in which war may be legitimately prosecuted.").

6. Haig v. Agee, 453 U.S. 280, 307 (1981) (citation omitted).

7. Lichter v. United States, 334 U.S. 742, 782 (1948).

8. In re Yamashita, 327 U.S. 1, 12 (1946).

9. Id.

10. U.S. CONST. art. II, $\$ 2$. 
response to threats to the national security and foreign policy of the United States. ${ }^{11}$ During the period leading up to the Constitution's ratification, the executive was understood as having the power to initiate hostilities and control conflict escalation. $^{12}$

By its terms, these provisions vest full control of the United States military forces in the President. The power of the President is at its zenith under the Constitution when directing military operations of the armed forces, because the power of Commander in Chief is assigned solely to the President, as the Court has confirmed. In The Prize Cases, for example, the Court explained that, whether the President "in fulfilling his duties as Commander in Chief" was justified in treating the southern States as belligerents and instituting a blockade, was a question "to be decided by him."13 The Court could not question the merits of his decision, but must leave evaluation to "the political department of the Government to which this power was entrusted." ${ }^{14}$ As the Court also observed, the President enjoys full discretion in determining what level of force to use. $^{15}$

11. See Johnson v. Eisentrager, 339 U.S. 763, 789 (1950) (noting that the President has authority to deploy United States armed forces "abroad or to any particular region"); Fleming v. Page, 50 U.S. (9 How.) 603, 615 (1850) ("As commander-in-chief, [the President] is authorized to direct the movements of the naval and military forces placed by law at his command, and to employ them in the manner he may deem most effectual ...."); Loving v. United States, 517 U.S. 748,776 (1996) (Scalia, J., concurring in part and concurring in judgment) (stating that the "inherent powers" of the Commander in Chief "are clearly extensive"); Maul v. United States, 274 U.S. 501, 515-16 (1927) (Brandeis \& Holmes, JJ., concurring) (" $\mathrm{T}]$ he President may direct any revenue cutter to cruise in any waters in order to perform any duty of the service."); Massachusetts v. Laird, 451 F.2d 26, 32 (1st Cir. 1971) (noting that the President has "power as Commander-inChief to station forces abroad"); Auth. to Use U.S. Military Forces in Somal., 16 Op. Off. Legal Counsel 6 (1992).

12. See John C. Yoo, The Continuation of Politics by Other Means: The Original Understanding of War Powers, 84 CAL. L. REV. 167, 196-241 (1996).

13. The Prize Cases, 67 U.S. (2 Black) 635, 670 (1862).

14. Id.

15. Id. ("He must determine what degree of force the crisis demands."); see Eisentrager, 339 U.S. at 789 ("Certainly it is not the function of the Judiciary to entertain private litigation - even by a citizen - which challenges the legality, the wisdom, or the propriety of the Commander-in-Chief in sending our armed forces abroad or to any particular region."); Chicago \& S. Air Lines v. Waterman Steamship Corp., 333 U.S. 103, 111 (1948) ("The President, both as Commander-inChief and as the Nation's organ for foreign affairs, has available intelligence services whose reports are not and ought not to be published to the world. It would be intolerable that courts, without the relevant information, should review and perhaps nullify actions of the Executive taken on information properly held 
Some commentators have read the constitutional text differently. They argue that Congress has the sole authority to decide whether to make war. ${ }^{16}$ This view, however, misinterprets the constitutional text and misunderstands the nature of a war declaration. Declaring war is not tantamount to making war; indeed, the Constitutional Convention specifically amended the working draft of the Constitution that had given Congress the power to "make" war. When it took up this clause on August 17, 1787, the Convention voted to change the clause from "make" to "declare."17 A supporter of the change argued that the new language would "leav[e] to the Executive the power to repel sudden attacks. ${ }^{18}$ In addition, other elements of

secret."); Ramirez de Arellano v. Weinberger, 745 F.2d 1500, 1561 (D.C. Cir. 1984) (Scalia, J., dissenting), vacated, 471 U.S. 1113 (1985) (arguing that majority should deny injunctive relief to plaintiffs because it would require the President to take the court into its confidence regarding military operations); Ex parte Vallandigham, 28 F. Cas. 874, 922 (C.C.S.D. Ohio 1863) (No. 16,816) ("[U]nder this power where there is no express legislative declaration, the president is guided solely by his own judgment and discretion ...."); Hefleblower v. United States, 21 Ct. Cl. 228, 238 (Ct. Cl. 1886) ("The responsibility of declaring what portions of the country were in insurrection and of declaring when the insurrection came to an end was accorded to the President; when he declared a portion of the country to be in insurrection the judiciary cannot try the issue and find the territory national; conversely, when the President declared the insurrection at an end in any portion of the country, the judiciary cannot try the issue and find the territory hostile."); cf. United States v. Chem. Found., Inc., 272 U.S. 1, 12 (1926) ("It was peculiarly within the province of the Commander-in-Chief to know the facts and to determine what disposition should be made of enemy properties in order effectively to carry on the war.").

16. See, e.g., LOUIS FISHER, PRESIDENTIAL WAR POWER 185-206 (1995); JOHN HART ELY, WAR AND RESPONSIBILITY: CONSTITUTIONAL LESSONS OF VIETNAM AND ITS AFIERMATH 3-5 (1993); MICHAEL J. GLENNON, CONSTITUTIONAL DIPLOMACY 80-84 (1990); LOUIS HENKIN, CONSTITUTIONALISM, DEMOCRACY, AND FOREIGN AFFAIRS 109 (1990); HAROLD HONGJU KOH, THE NATIONAL SECURITY CONSTITUTION: SHARING POWER AFTER THE IRAN-CONTRA AFFAIR 158-61 (1990); FRANCIS D. WORMUTH \& EDWIN B. FIRMAGE, TO CHAIN THE DOG OF WAR: THE WAR POWER OF CONGRESS IN HISTORY AND LAW (2d ed. 1989). Other scholars, however, have argued that the President has the constitutional authority to initiate military hostilities without prior congressional authorization. See, e.g., EDWARD S. CORWIN, THE PRESIDENT: OFFICE AND POWERS 1787-1984 (5th ed. 1984); Philip Bobbitt, War Powers: An Essay on John Hart Ely's "War and Responsibility: Constitutional Lessons of Vietnam and Its Aftermath," $92 \mathrm{MiCH}$. L. REV. 1364 (1994); Robert H. Bork, Erosion of the President's Power in Foreign Affairs, 68 WASH. U. L.Q. 693 (1990); Henry P. Monaghan, Presidential War-Making, 50 B.U. L. REV. 19 (1970); W. Michael Reisman, Some Lessons from Iraq: International Law and Democratic Politics, 16 YALE J. INT'L L. 203 (1991); Eugene V. Rostow, "Once More unto the Breach:" The War Powers Resolution Revisited, 21 VAL. U. L. REV. 1 (1986); John C. Yoo, Kosovo, War Powers, and the Multilateral Future, 148 U. PA. L. REV. 1673 (2000); Yoo, supra note 12.

17. 2 THE RECORDS OF THE FEDERAL CONVENIION OF 1787, at 318-19 (Max Farrand ed., rev. ed. 1966).

18. Id. at 318 . 
the Constitution describe "engaging" in war. ${ }^{19}$ This fact demonstrates that the Framers understood "making" and "engaging" in war to be somewhat broader than simply "declaring" war. A State constitution at the time of the ratification included provisions that prohibited the governor from "making" war without legislative approval. ${ }^{20}$ If the Framers had wanted to require congressional consent before the initiation of military hostilities, they would have used such language.

Finally, the Framer's generation also understood that declarations of war were becoming obsolete. Not all forms of hostilities rose to the level of a "declared" war. During the seventeenth and eighteenth centuries, for example, Great Britain and colonial America waged numerous conflicts against other nations without an official declaration of war. ${ }^{21}$ As Alexander Hamilton observed during the ratification, "the ceremony of a formal denunciation of war has of late fallen into disuse."22 Instead of serving as an authorization to begin hostilities, a declaration of war was only necessary to "perfect" a conflict under international law. A declaration served to fully transform the international legal relationship between two states from one of peace to one of war. ${ }^{23}$ Given this contextual understanding, Congress's power to "declare" war would not

19. See U.S. CONST. art. I, $\$ 10$ ("No State shall, without the Consent of Congress ... engage in War, unless actually invaded, or in such imminent Danger as will not admit of delay.").

20. S.C. CONST. art. XXVI (1776), reprinted in 6 THE FEDERAL AND STATE CONSTITUTIONS 3241, 3247 (Francis Newton Thorpe ed., 1909). A subsequent version made clear "that the governor and commander-in-chief shall have no power to commence war, or conclude peace, or enter into any final treaty" without legislative approval. S.C. CONST. art. XXXIII (1778), reprinted in 6 THE FEDERAL AND STATE CONSTTIUTIONS, supra, at 3248, 3255.

21. Of the eight major wars fought by Great Britain prior to the ratification of the Constitution, war was declared only once before the start of hostilities. See Yoo, supra note 12, at 214-15; see also W. TAYLOR REVELEY, III, WAR POWERS OF THE PRESIDENT AND CONGRESS: WHO HOLDS THE ARROWS AND OLIVE BRANCH? 55 (1981) ("[U]ndeclared war was the norm in eighteenth-century European practice, a reality brought home to Americans when Britain's Seven Years' War with France began on this continent.").

22. THE FEDERALIST NO. 25, at 133 (Alexander Hamilton) (Clinton Rossiter ed., 1961).

23. See 1 WILLIAM BLACKSTONE, COMMENTARIES ON THE LAWS OF ENGLAND *249-50 (1770); see also James Madison, Helvidius No. 1, PHILADELPHIA GAZETTE OF THE U.S., Aug. 18 \& 24, 1793, reprinted in 15 THE PAPERS OF JAMES MADISON 72 (Thomas A. Mason et al. eds., 1985) ("The power of making treaties and the power of declaring war, are royal prerogatives in the British government, and are accordingly treated as Executive prerogatives by British commentators."). 
limit the President's independent and plenary constitutional authority over the use of military force.

\section{B. Constitutional Structure}

Our reading of the text is reinforced by analysis of the constitutional structure. First, it is clear that the Constitution secures all federal executive power in the President to ensure a unity in purpose and energy in action. "Decision, activity, secrecy, and dispatch will generally characterize the proceedings of one man in a much more eminent degree than the proceedings of any greater number. ${ }^{24}$ The centralization of authority in the President alone is particularly crucial in matters of national defense, war, and foreign policy, where a unitary executive can evaluate threats, consider policy choices, and mobilize military and diplomatic resources with a speed and energy that is far superior to any other branch. As Hamilton noted, "[e]nergy in the executive is a leading character in the definition of good government. It is essential to the protection of the community against foreign attacks. ${ }^{25}$ This point applies to the war context as well. "Of all the cares or concerns of government, the direction of war most peculiarly demands those qualities which distinguish the exercise of power by a single hand. ${ }^{26}$

Second, the Constitution makes clear that the process used for conducting military hostilities is different from other government decision-making practices. In the area of domestic legislation, the Constitution creates a detailed, finely wrought procedure in which Congress plays the central role. In foreign affairs, however, the Constitution does not establish a

24. THE FEDERALIST NO. 70, at 392 (Alexander Hamilton) (Clinton Rossiter ed., 1961).

25. Id. at 391.

26. THE FEDERALIST NO. 74, at 415 (Alexander Hamilton) (Clinton Rossiter ed., 1961). Future Supreme Court Justice James Iredell argued that "[f]rom the nature of the thing, the command of armies ought to be delegated to one person only. The secrecy, $\mathrm{d}[\mathrm{i}] \mathrm{spatch}$, and decision, which are necessary in military operations, can only be expected from one person." Debate in the North Carolina Ratifying Convention, in 4 THE DEBATES IN THE SEVERAL STATE CONVENTIONS ON THE ADOPTION OF THE FEDERAL CONSTITUTION AS RECOMMENDED BY THE GENERAL CONVENTION AT PHILADELPHIA IN 1787, at 107 (Jonathan Elliot ed., 2d ed. 1987). See also 2 JOSEPH STORY, COMMENTARIES ON THE CONSTITUTION OF THE UNITED STATES § 1491 (1833) (stating that in military matters, "[u]nity of plan, promptitude, activity, and decision, are indispensable to success; and these can scarcely exist, except when a single magistrate is entrusted exclusively with the power"). 
mandatory, detailed, congressionally driven procedure for taking action. Rather, the Constitution vests the two branches with different powers - the President as Commander in Chief, and the Congress with control over funding and declaring war-without requiring that they follow a specific process in making war. By establishing this framework, the Framers expected that the process for war making would be more flexible, and capable of quicker, more decisive action, than the legislative process. Thus, the President may use his commander-in-chief and executive powers to use military force to protect the nation, subject to congressional appropriation and control over domestic legislation.

Third, the constitutional structure requires that any ambiguities in the allocation of a power that is executive in nature, such as the power to conduct military hostilities, must be resolved in favor of the executive branch. Article II, Section 1 provides that "[t]he executive Power shall be vested in a President of the United States." ${ }^{27}$ By contrast, Article I's Vesting Clause gives Congress only the powers "herein granted." ${ }^{28}$ This difference in language indicates that Congress's legislative powers are limited to the list enumerated in Article I, Section 8, while the President's powers include inherent executive powers that are unenumerated in the Constitution.

To be sure, Article II lists specifically enumerated powers in addition to the Vesting Clause, and some have argued that this limits the "executive Power" granted in the Vesting Clause to the powers on that list. The purpose of the enumeration of executive powers in Article II, however, was not to define and cabin the grant in the Vesting Clause. Rather, the Framers redirected some elements of powers that had traditionally been regarded as "executive", assigning them to Congress in Article I, while expressly maintaining other elements as enumerated executive powers in Article II. Hence, for example, they gave the King's traditional power to declare war to Congress under Article I, while the commander-in-chief authority was expressly reserved for the President in Article II. Furthermore, the Framers altered other plenary powers of the King, such as treaties and appointments, assigning the Senate a share of them

27. U.S. CONST. art. II, § 1.

28. U.S. CONST. art. I, §1. 
in Article II itself. Thus, Article II's enumeration of the Treaty and Appointments Clauses only dilutes the unitary nature of the executive branch in regard to the exercise of those powers, rather than transforming them into quasi-legislative functions. ${ }^{29}$ Thus, the enumeration in Article II marks the places where several traditional executive powers were diluted or reallocated. The Vesting Clause, however, conveyed all other unenumerated executive powers to the President.

There can be little doubt that the decision to deploy military force is "executive" in nature, and was traditionally regarded as such. It calls for action and energy in execution, rather than the deliberate formulation of rules to govern the conduct of private individuals. Moreover, the Framers understood it to be an attribute of the executive. "The direction of war implies the direction of the common strength," wrote Alexander Hamilton, "and the power of directing and employing the common strength forms a usual and essential part in the definition of the executive authority. ${ }^{130}$ As a result, to the extent that the constitutional text does not explicitly allocate the power to initiate military hostilities to a particular branch, the Vesting Clause provides that it remain among the President's unenumerated powers.

Fourth, depriving the President of the power to decide when to use military force would disrupt the basic constitutional framework for foreign relations. From the beginning of the Republic, the vesting of the executive, commander-in-chief, and treaty-making powers in the executive branch has been understood as granting the President plenary control over the conduct of foreign relations. As Secretary of State Thomas Jefferson observed during the first Washington Administration, "the constitution has divided the powers of government into three branches [and] has declared that 'the executive powers shall be vested in the president,' submitting only special articles of it to a negative by the senate. ${ }^{\prime \prime 1}$ Due to this structure,

29. See Constitutionality of Proposed Conditions to Senate Consent to the Interim Convention on Conservation of North Pacific Fur Seals, 10 Op. Off. Legal Counsel 12, 17 (1986) ("Nothing in the text of the Constitution or the deliberations of the Framers suggests that the Senate's advice and consent role in the treatymaking process was intended to alter the fundamental constitutional balance between legislative authority and executive authority.").

30. THE FEDERALIST NO. 74, supra note 26, at 415.

31. Thomas Jefferson, Opinion on the Powers of the Senate (Apr. 24, 1790), 
Jefferson continued, " $[t]$ he transaction of business with foreign nations is executive altogether; it belongs, then, to the head of that department, except as to such portions of it as are specially submitted to the senate. Exceptions are to be construed strictly . ..." ${ }^{\prime \prime 2}$ In defending President Washington's authority to issue the Neutrality Proclamation, Alexander Hamilton came to the same interpretation of the President's foreign affairs powers. According to Hamilton, Article II "ought ... to be considered as intended ... to specify and regulate the principal articles implied in the definition of Executive Power; leaving the rest to flow from the general grant of that power ...." ${ }^{\prime 33}$ As future Chief Justice John Marshall famously declared a few years later: "The President is the sole organ of the nation in its external relations, and its sole representative with foreign nations. ... The [executive] department ... is entrusted with the whole foreign intercourse of the nation . . .".34 Given the agreement of Jefferson, Hamilton, and Marshall, it has not been difficult for the executive branch to consistently assert the President's plenary authority in foreign affairs ever since.

On the relatively few occasions where it has addressed foreign affairs, the Supreme Court has agreed with the executive branch's interpretation. Conducting foreign affairs and protecting the national security are, as the Supreme Court has observed, "'central' Presidential domains." ${ }^{35}$ The President's constitutional primacy flows from both his unique position in the constitutional structure and from the specific grants of authority in Article II that make the President both the Chief Executive of the nation and the Commander in Chief. ${ }^{36}$ Due to the President's constitutionally superior position, the Supreme Court has consistently "recognized 'the generally accepted view that foreign policy [is] the province and responsibility of the Executive." wisdom made [the President] not only the Commander-in-

reprinted in 5 THE WRITINGS OF ThOMAS JefFerson 161, 161 (Paul L. Ford ed., 1895).

32. $I d$.

33. Alexander Hamilton, Pacificus No. 1 (1793), reprinted in 15 THE PAPERS OF ALEXANDER HAMILTON 33, 39 (Harold C. Syrett et al. eds., 1969).

34. 10 ANNALS OF CONG. 613-14 (1800).

35. Harlow v. Fitzgerald, 457 U.S. 800,812 n.19 (1982).

36. Nixon v. Fitzgerald, 457 U.S. 731, 749-50 (1982).

37. Dep't of the Navy v. Egan, 484 U.S. 518, 529 (1988) (quoting Haig v. Agee, 453 U.S. 280, 293-94 (1981)). 
Chief but also the guiding organ in the conduct of our foreign affairs," possessing "vast powers in relation to the outside world." ${ }^{38}$ This foreign affairs power is exclusive; it is "the very delicate, plenary and exclusive power of the President as sole organ of the federal government in the field of international relations-a power which does not require as a basis for its exercise an act of Congress." ${ }^{139}$

Conducting military hostilities is a central tool for the exercise of the President's plenary control over the conduct of foreign policy. There can be no doubt that the use of force protects the nation's security and helps it achieve its foreign policy goals. Construing the Constitution to grant such power to another branch could prevent the President from exercising his core constitutional responsibilities in foreign affairs. Even in the cases in which the Supreme Court has limited executive authority, it has also emphasized that we should not construe legislative prerogatives to prevent the executive branch "from accomplishing its constitutionally assigned functions." ${ }^{\prime 40}$

\section{EXECUTIVE BRANCH CONSTRUCTION AND PRACTICE}

The position we take here has long represented the view of the executive branch and of the Department of Justice across many administrations of different political parties. Attorney General (later Justice) Robert Jackson formulated the classic statement of the executive branch's understanding of the President's military powers in 1941:

Article II, section 2, of the Constitution provides that the President "shall be Commander in Chief of the Army and Navy of the United States." By virtue of this constitutional office he has supreme command over the land and naval forces of the country and may order them to perform such military duties as, in his opinion, are necessary or appropriate for the defense of the United States. These powers exist in time of peace as well as in time of war....

Thus the President's responsibility as Commander in Chief embraces the authority to command and direct the armed forces in their immediate movements and operations designed to protect the security and effectuate the defense of the United States. ... [T] [Tis authority undoubtedly includes

38. Ludecke v. Watkins, 335 U.S. 160, 173 (1948).

39. United States v. Curtiss-Wright Exp. Corp., 299 U.S. 304, 320 (1936).

40. Nixon v. Adm'r of Gen. Serv., 433 U.S. 425, 443 (1977). 
the power to dispose of troops and equipment in such manner and on such duties as best to promote the safety of the country. ${ }^{41}$

Other Attorneys General have defended similar accounts of the President constitutional powers and duties, particularly in times of unforeseen emergencies. Attorney General William P. Barr, quoting the opinion of Attorney General Jackson just cited, advised the President in 1992: "You have authority to commit troops overseas without specific prior Congressional approval 'on missions of good will or rescue, or for the purpose of protecting American lives or property or American interests.' ${ }^{\prime 42}$ Attorney General (later Justice) Frank Murphy, though declining to define precisely the scope of the President's independent authority to act in emergencies or states of war, stated:

[T] The Executive has powers not enumerated in the statutespowers derived not from statutory grants but from the Constitution. It is universally recognized that the constitutional duties of the Executive carry with them the constitutional powers necessary for their proper performance. These constitutional powers have never been specifically defined, and in fact cannot be, since their extent and limitations are largely dependent upon conditions and circumstances. ... The right to take specific action might not exist under one state of facts, while under another it might be the absolute duty of the Executive to take such action.

Attorney General Thomas Gregory opined in 1914 that, "[i]n the preservation of the safety and integrity of the United States and the protection of its responsibilities and obligations as a sovereignty, [the President's] powers are broad. ${ }^{\prime 44}$ Finally, in 1898, Acting Attorney General John K. Richards wrote:

The preservation of our territorial integrity and the

41. Training of British Flying Students in the U.S., 40 Op. Att'y Gen. 58, 61-62 (1941). At the time Attorney General Jackson delivered his opinion, the United States was a neutral, and thus his conclusions about the President's powers did not rest on any special considerations that might apply in time of war. Although he stated that he was "inclined to the opinion" that a statute (the Lend-Lease Act) authorized the decision under review, Jackson expressly based his conclusion on the President's constitutional authority. Id. at 61 .

42. Auth. to Use U.S. Military Forces in Somal., supra note 11, at 6 (quoting Training of British Flying Students in the U.S., supra note 41, at 62).

43. Request of the Senate for an Opinion as to the Powers of the President "In Emergency or State of War," 39 Op. Att'y Gen. 343, 347-48 (1939).

44. Censorship of Radio Stations, 30 Op. Att'y Gen. 291, 292 (1914). 
protection of our foreign interests is [e]ntrusted, in the first instance, to the President. . . . In the protection of these fundamental rights, which are based upon the Constitution and grow out of the jurisdiction of this nation over its own territory and its international rights and obligations as a distinct sovereignty, the President is not limited to the enforcement of specific acts of Congress. ... [The President] must preserve, protect, and defend those fundamental rights which flow from the Constitution itself and belong to the sovereignty it created. ${ }^{45}$

\section{A. Opinions of the Office of Legal Counsel}

In recent Administrations, the Office of Legal Counsel of the Department of Justice (OLC) has taken the position that the President may unilaterally deploy military force in order to protect the national security and interests of the United States. By statute, the Attorney General is vested with the authority to interpret constitutional and statutory provisions on behalf of the executive branch. By regulation, the Attorney General has delegated this function to OLC. As a result, OLC's interpretation of federal law is definitive within the executive branch.

In Deployment of United States Armed Forces into Haiti, ${ }^{46}$ OLC advised that President Clinton had the authority to unilaterally deploy over 20,000 troops into Haiti. It relied, in part, on the structure of the War Powers Resolution, which we argued "makes sense only if the President may introduce troops into hostilities or potential hostilities without prior authorization by the Congress." ${ }^{\prime 7}$ OLC further argued that "in establishing and funding a military force that is capable of being projected anywhere around the globe, Congress has given the President, as Commander in Chief, considerable discretion in deciding how that force is to be deployed." 48 OLC also cited and relied upon the past practice of the executive branch in undertaking

45. Foreign Cables, 22 Op. Att'y Gen. 13, 25-26 (1898). Acting Attorney General Richards cited, among other judicial decisions, Cunningham v. Neagle, 135 U.S. 1, 64 (1890), in which the Supreme Court stated that the President's power to enforce the laws of the United States "include[s] the rights, duties and obligations growing out of the constitution itself, our international relations, and all the protection implied by the nature of the government under the constitution."

46. 18 Op. Off. Legal Counsel 173 (1994).

47. Id. at 175-76.

48. Id. at 177 . 
unilateral military interventions:

In 1940, after the fall of Denmark to Germany, President Franklin Roosevelt ordered United States troops to occupy Greenland, a Danish possession in the North Atlantic of vital strategic interest to the United States. . . . Congress was not consulted or even directly informed. . . . Later, in 1941, the President ordered United States troops to occupy Iceland, an independent nation, pursuant to an agreement between himself and the Prime Minister of Iceland. The President relied upon his authority as Commander in Chief, and notified Congress only after the event. . . . More recently, in 1989, at the request of President Corazon Aquino, President Bush authorized military assistance to the Philippine government to suppress a coup attempt. ${ }^{49}$

In Authority to Use United States Military Forces in Somalia, ${ }^{50}$ OLC advised that the President had the constitutional authority to deploy United States Armed Forces into Somalia in order to assist the United Nations in ensuring the safe delivery of relief to distressed areas of that country. OLC stated that "the President's role under our Constitution as Commander in Chief and Chief Executive vests him with the constitutional authority to order United States troops abroad to further national interests such as protecting the lives of American citizens overseas. ${ }^{151}$ Citing past practice, OLC established that:

From the instructions of President Jefferson's Administration to Commodore Richard Dale in 1801 to 'chastise' Algiers and Tripoli if they continued to attack American shipping, to the present, Presidents have taken military initiatives abroad on the basis of their constitutional authority. ... Against the background of this repeated past practice under many Presidents, this Department and this Office have concluded that the President has the power to commit United States troops abroad for the purpose of protecting important national interests. ${ }^{52}$

In Overview of the War Powers Resolution, ${ }^{53}$ OLC noted that "[t]he President's authority to deploy armed forces has been exercised in a broad range of circumstances [in] our history." 54

49. Id. at 178 .

50. 16 Op. Off. Legal Counsel 8 (1992).

51. Id. at 9.

52. Id. (citations omitted).

53. 8 Op. Off. Legal Counsel 271 (1984).

54. Id. at 275. 
In Presidential Power to Use the Armed Forces Abroad Without Statutory Authorization, ${ }^{55}$ OLC stated:

Our history is replete with instances of presidential uses of military force abroad in the absence of prior congressional approval. This pattern of presidential initiative and congressional acquiescence may be said to reflect the implicit advantage held by the executive over the legislature under our constitutional scheme in situations calling for immediate action. Thus, constitutional practice over two centuries, supported by the nature of the functions exercised and by the few legal benchmarks that exist, evidences the existence of broad constitutional power. ${ }^{56}$

In light of that understanding, OLC advised that the President had independent constitutional authority unilaterally to order "(1) deployment abroad at some risk of engagementfor example, the current presence of the fleet in the Persian Gulf region; (2) a military expedition to rescue the hostages or to retaliate against Iran if the hostages are harmed; (3) an attempt to repel an assault that threatens our vital interests in that region. ${ }^{157}$

\section{B. Judicial Construction}

Since the beginning of the Republic, judicial decisions have confirmed the President's constitutional power and duty to repel military action against the United States through the use of force and to take measures to deter the recurrence of an attack. As Justice Joseph Story said long ago, "[i]t may be fit and proper for the government, in the exercise of the high discretion confided to the executive, for great public purposes, to act on a sudden emergency, or to prevent an irreparable mischief, by summary measures, which are not found in the text of the laws." 58 The Constitution entrusts the "power [to] the executive branch of the government to preserve order and insure the public safety in times of emergency, when other

55. 4A Op. Off. Legal Counsel 185 (1980).

56. Id. at 187.

57. Id. at 185-86. See also Presidential Powers Relating to the Situation in Iran, 4A Op. Off. Legal Counsel 115, 121 (1979) ("It is well established that the President has the constitutional power as Chief Executive and Commander-inChief to protect the lives and property of Americans abroad. This understanding is reflected in judicial decisions. .... and recurring historic practice which goes back to the time of Jefferson.").

58. The Apollon, 22 U.S. (9 Wheat.) 362, 366-67 (1824). 
branches of the government are unable to function, or their functioning would itself threaten the public safety. ${ }^{159}$

If an unforeseen attack on the territory and people of the United States or other immediate, dangerous threat to American interests and security confronts the President, the courts have affirmed that it is his constitutional responsibility to respond to that threat with whatever means are necessary, including the use of military force abroad. ${ }^{60}$

\section{HISTORICAL SUPPORT}

\section{A. The Historical Practice of the Three Branches}

The historical practice of all three branches of government confirms the lessons of the constitutional text and structure. The normative role of historical practice in constitutional law, and especially with regard to separation of powers, is well settled. $^{61}$ Both the Supreme Court and the political branches have often recognized that governmental practice plays a

59. Duncan v. Kahanamoku, 327 U.S. 304, 335 (1946) (Stone, C.J., concurring).

60. See, e.g., The Prize Cases, 67 U.S. (2 Black) 635, 668 (1862) ("If a war be made by invasion of a foreign nation, the President is not only authorized but bound to resist force by force ... without waiting for any special legislative authority."); Duncan, 327 U.S. at 336 (Stone, C.J., concurring) ("The Executive has broad discretion in determining when the public emergency is such as to give rise to the necessity" for emergency measures); United States v. Smith, 27 F. Cas. 1192, 1230 (C.C.D.N.Y. 1806) (No. 16,342) (Paterson, Circuit Justice) (regardless of statutory authorization, it is "the duty ... of the executive magistrate ... to repel an invading foe"); Mitchell v. Laird, 488 F.2d 611, 613 (D.C. Cir. 1973) ("[T]here are some types of war which without Congressional approval, the President may begin to wage: for example, he may respond immediately without such approval to a belligerent attack"); Campbell v. Clinton, 203 F.3d 19, 27 (D.C. Cir. 2000) (Silberman, J., concurring) ("[T]he President has independent authority to repel aggressive acts by third parties even without specific statutory authorization."), cert. denied, 531 U.S. 815 (2000); id. at 40 (Tatel, J., concurring) ("[T]he President, as Commander in Chief, possesses emergency authority to use military force to defend the nation from attack without obtaining prior congressional approval."); see also STORY, supra note $26, \S 1485$ ("The command and application of the public force ... to maintain peace, and to resist foreign invasion" are executive powers).

61. As the Supreme Court has noted, "the decisions of the Court in th[e] area [of foreign affairs] have been rare, episodic, and afford little precedential value for subsequent cases." Dames \& Moore v. Regan, 453 U.S. 654, 661 (1981). In particular, the difficulty the courts experience in addressing "the broad range of vitally important day-to-day questions regularly decided by Congress or the Executive" with respect to foreign affairs and national security makes the judiciary "acutely aware of the necessity to rest [judicial] decision[s] on the narrowest possible ground capable of deciding the case." Id. at 660-61. Historical practice and the ongoing tradition of executive branch constitutional interpretation therefore play an important role in this area. 
highly significant role in establishing the contours of the constitutional separation of powers. Indeed, as the Court has observed, the role of practice in fixing the meaning of the separation of powers is implicit in the Constitution itself: "'T]he Constitution .. . contemplates that practice will integrate the dispersed powers into a workable government."'62 In addition, governmental practice enjoys significant weight in constitutional analysis for practical reasons, on "the basis of a wise and quieting rule that, in determining ... the existence of a power, weight shall be given to the usage itself-even when the validity of the practice is the subject of investigation." ${ }^{\prime 63}$

The role of practice in assessing constitutionality is heightened in issues affecting foreign affairs and national security, where "the Court has been particularly willing to rely on the practical statesmanship of the political branches when considering constitutional questions . ..."64 "The persistence of these controversies (which trace back to the eighteenth century), and the nearly complete absence of judicial decisions resolving them, underscore the necessity of relying on congressional precedent to interpret the relevant constitutional provisions." ${ }^{65}$ Accordingly, the Court should give considerable weight to the practice of the political branches in trying to determine the constitutional allocation of war-making powers between them.

The historical record demonstrates that the power to initiate military hostilities, particularly in response to the threat of an armed attack, rests exclusively with the President. As the Supreme Court has observed, "[t]he United States frequently employs Armed Forces outside this country-over 200 times in our history - for the protection of American citizens or national security." ${ }^{66}$ At least 125 deployments of this sort, where the President acted without prior express authorization from

62. Mistretta v. United States, 488 U.S. 361, 381 (1989) (quoting Youngstown Sheet \& Tube v. Sawyer, 343 U.S. 579, 635 (1952) (Jackson, J., concurring)).

63. United States v. Midwest Oil Co., 236 U.S. 459, 473 (1915). For a "Coasian" explanation of the significance of practice to separation of powers doctrine, see John O. McGinnis, Constitutional Review by the Executive in Foreign Affairs and War Powers: A Consequence of Rational Choice in the Separation of Powers, 56 LAW \& CONTEMP. PROBS. 293 (1993).

64. Whether Uruguay Round Agreements Required Ratification as a Treaty, 18 Op. Off. Legal Counsel 232, 234 (1994).

65. Id. at 236.

66. United States v. Verdugo-Urquidez, 494 U.S. 259, 273 (1990). 
Congress, have occurred since the Administration of George Washington. ${ }^{67}$ Perhaps the most significant operation exercised on the President's sole authority occurred during the Korean War, when President Truman ordered United States troops to fight a war that lasted for over three years and resulted in over 142,000 American casualties.

Recent commitments of the nation's military personnel, diplomatic prestige, and financial resources based exclusively on the President's constitutional authority have also been substantial. On at least one occasion, such a unilateral deployment has constituted a full-scale war. On March 24, 1999, without any prior statutory authorization and in the absence of an attack on the United States, President Clinton ordered hostilities to be initiated against the Republic of Yugoslavia. The President informed Congress that, in the initial wave of air strikes, "United States and NATO forces have targeted the [Yugoslavian] government's integrated air defense system, military and security police command and control elements, and military and security police facilities and infrastructure. ... I have taken these actions pursuant to my constitutional authority to conduct U.S. foreign relations and as Commander in Chief and Chief Executive. ${ }^{\prime 68}$ Bombing attacks against targets in both Kosovo and Serbia ended on June 10, 1999, seventy-nine days after the war began. More than 30,000 United States military personnel participated in the operations; some 800 U.S. aircraft flew more than 20,000 sorties; and the forces together used more than 23,000 bombs and missiles. As part of the peace settlement, NATO deployed some 50,000 troops into Kosovo; 7,000 of them were American. ${ }^{69}$

In a news briefing on June 10, 1999, Secretary of Defense

67. See David P. Currie, The Constitution in Congress: Substantive Issues in the First Congress, 1789-1791, 61 U. CHI. L. REV. 775, 816 (1994) ("[B]oth Secretary [of War] Knox and [President] Washington himself seemed to think that this [Commander in Chief] authority extended to offensive operations taken in retaliation for Indian atrocities.").

68. Letter to Congressional Leaders Reporting on Airstrikes Against Serbian Targets in the Federal Republic of Yugoslavia (Serbia and Montenegro), 1 PUB. PAPERS 459 (Mar. 26, 1999).

69. See Campbell v. Clinton, 203 F.3d 19, 40 (D.C. Cir. 2000) (Tatel, J., concurring) (quoting testimony of Secretary of Defense Cohen that " $[w]$ ' re certainly engaged in hostilities [in Yugoslavia], we're engaged in combat"); Exec. Order No. 13,119, 64 Fed. Reg. 18,797 (Apr. 16, 1999) (designating March 24, 1999, as "the date of the commencement of combatant activities" in Yugoslavia); John C. Yoo, US Wars, US War Powers, 1 CHI. J. INT'L L. 355 (2000). 
William S. Cohen summarized the effects of the campaign by saying:

[T]hree months ago Yugoslavia was a heavily armed country with a significant air defense system. We reduced that defense system threat by destroying over 80 percent of Yugoslavia's modern aircraft fighters and strategic surfaceto-air missiles. NATO destroyed a significant share of the infrastructure Yugoslavia used to support[] its military with, we reduced his capacity to make ammunition by two-thirds, and we eliminated all of its oil refining capacity and more than 40 percent of its military fuel supplies. Most important, we severely crippled the military forces in Kosovo by destroying more than 50 percent of the artillery and more than one-third of the armored vehicles. ${ }^{70}$

General Shelton of the Joint Chiefs of Staff reported that:

about half of [Yugoslavia's] defense industry has either been damaged or destroyed. . . . [A]viation, 70 percent; armored vehicle production, 40 [percent]; petroleum refineries, 100 percent down; explosive production, about 50 percent; and 65 percent of his ammunition. ... For the most part Belgrade is a city that's got about probably 70 percent without [electrical] power.

A report by General Ryan, Air Force Chief of Staff, on June 8, 1999, stated that "Serbia's air force is essentially useless and its air defenses are dangerous but ineffective . ..."72 Estimates near the time placed the number of Yugoslav military casualties at between five and ten thousand. ${ }^{73}$ In recent decades, no President has unilaterally deployed so much force abroad.

Other recent unilateral deployments have also utilized considerable military, diplomatic, and financial resources. Many of these deployments occurred in the Balkans during the mid-1990s. ${ }^{74}$ In December 1995, for example, President Clinton ordered 20,000 United States military personnel to Bosnia to

70. News Briefing, Office of the Assistant Secretary of Defense (Public Affairs), U.S. Dep't of Defense (June 10, 1999), available at http://www.defenselink.mil/ news/Jun1999/t06101999_t0610asd.html (remarks of Secretary Cohen).

71. Id. (remarks of Gen. Shelton).

72. General Michael E. Ryan, It May Take Time, but It's Inevitable, AIR FORCE NEwS, June 8, 1999, http://www.af.mil/news/Jun199/n19990608_991134.html.

73. Nick Cook, War of Extremes, JANE'S DEFENSE WEEKLy, July 7, 1999, at 20, 21. available at http://www.janes.com/defense/news/kosovo/jdw990707_01_n. shtml.

74. See Yoo, supra note 69 , at 359. 
implement a peace settlement. In February 1994, sixty United States warplanes conducted air strikes against Yugoslav targets. In 1993, the United States sent warplanes to enforce a no-fly zone over Bosnia; in the same year, the President dispatched United States troops to Macedonia as part of a United Nations peacekeeping operation.

Outside the Balkans, President Clinton sent some 20,000 United States troops to Haiti in 1994, again without prior statutory authorization from Congress, based solely upon his Article II authority. ${ }^{75}$ On August 8, 1990, in response to the Iraqi invasion of Kuwait and the consequent threat to Saudi Arabia, President Bush deployed a substantial force in Operation Desert Shield, including two squadrons of F-15 aircraft and a brigade of the 82 nd Airborne Division. It eventually grew to several hundred thousand. The President informed Congress that he had taken these actions "pursuant to my constitutional authority to conduct our foreign relations and according to my power as Commander in Chief." ${ }^{\prime 76}$ President Bush had also sent some 15,000 troops into Panama in December 1990, for the purpose of protecting American citizens there. ${ }^{77}$

Further, when Congress has actually authorized troop deployments in hostilities, Presidents have taken the position that such legislation, although welcome, was not constitutionally necessary. For example, in signing Pub. L. No. $102-01,{ }^{78}$ authorizing the use of military force in Operation Desert Storm against Iraq, President Bush stated that "my request for congressional support did not, and my signing this resolution does not, constitute any change in the long-standing positions of the executive branch on either the President's constitutional authority to use the Armed Forces to defend vital U.S. interests or the constitutionality of the War Powers Resolution."79 Similarly, President John F. Kennedy stated on

75. See Deployment of U.S. Armed Forces into Haiti, 18 Op. Off. Legal Counsel 173 (1994).

76. Letter to the Speaker of the House and the President Pro Tempore of the Senate on the Deployment of U.S. Armed Forces to Saudi Arabia and the Middle East, 2 PUB. PAPERS 1116 (Aug. 9, 1990).

77. See generally Abraham D. Sofaer, The Legality of the United States Action in Panama, 29 Colum. J. Transnat'l L. 281 (1991).

78. 105 Stat. 3 (1991).

79. Statement on Signing the Resolution Authorizing the Use of Military Force 
September 13, 1962, that congressional authorization for a naval blockade of Cuba was unnecessary, maintaining that "I have full authority now to take such action." ${ }^{110}$ In a Report to the American People on October 22, 1962, President Kennedy asserted that he had ordered the blockade "under the authority entrusted to me by the Constitution as endorsed by the resolution of the Congress. ${ }^{\text {" }} 1$ Thus, abundant precedent exists supporting the deployment of military force abroad, including the waging of war, on the basis of the President's sole constitutional authority.

\section{B. Recent Precedents}

Of particular relevance to the present situation are three recent precedents that concern terrorists. The most relevant precedent is the military action that President Clinton ordered on August 20,1998, against terrorist sites in Afghanistan and Sudan. The second is the strike on Iraqi Intelligence Headquarters that President Clinton ordered on June 26, 1993. The third is President Ronald Reagan's action on April 14, 1986, ordering United States armed forces to attack selected targets at Tripoli and Benghazi, Libya.

\section{The 1998 Strikes on Terrorist Facilities in Afghanistan and Sudan}

On August 20, 1998, President Clinton ordered the Armed Forces to strike at terrorist-related facilities in Afghanistan and Sudan "because of the threat they present to our national security." ${ }^{12}$ The President stated that the purpose of the operation was "to strike at the network of radical groups affiliated with and funded by Osama bin Laden, perhaps the

\footnotetext{
Against Iraq, 1 PUB. PAPERS 40 Jan. 14, 1991). Further, in a press conference on January 9, 1991, President Bush was asked if he believed that he needed congressional authorization in order to begin offensive operations against Iraq. He answered, "I don't think I need it. I think Secretary Cheney expressed it very well the other day. There are different opinions on either side of this question, but Saddam Hussein should be under no question on this: I feel that I have the authority to fully implement the United Nations resolutions." The President's News Conference on the Persian Gulf Crisis, 1 PUB. PAPERS 17, 20 (Jan. 9, 1991).

80. Statements Regarding the Cuban Missile Crisis, 1 PUB. PAPERS 674 (Sept. 13, 1962).

81. Id. at 807 (emphasis added).

82 Remarks on Departure for Washington, DC, from Martha's Vineyard, Mass.: Military Action Against Terrorist Sites in Afg. and Sudan, 2 PuB. PAPERS 1460, 1460 (Aug. 20, 1998).
} 
preeminent organizer and financier of international terrorism in the world today. ${ }^{\prime 83}$ The strike was ordered in retaliation for the bombings of the United States embassies in Kenya and Tanzania, which caused the deaths of some 12 Americans and nearly 300 Kenyans and Tanzanians, and to deter later terrorist attacks of a similar kind against United States nationals and others. In his remarks at Martha's Vineyard, the President justified the operation as follows:

I ordered this action for four reasons: first, because we have convincing evidence these groups played the key role in the Embassy bombings in Kenya and Tanzania; second, because these groups have executed terrorist attacks against Americans in the past; third, because we have compelling information that they were planning additional terrorist attacks against our citizens and others with the inevitable collateral casualties we saw so tragically in Africa; and fourth, because they are seeking to acquire chemical weapons and other dangerous weapons. ${ }^{84}$

In his Address to the Nation on the same day, the President made clear that the strikes were aimed, not only at Osama bin Laden's organization, but at other terrorist groups thought to be affiliated with it, and that the strikes were intended as retribution for other incidents caused by these groups, and not merely the then-recent bombings of the two United States embassies. Referring to the past acts of the interlinked terrorist groups, he stated:

Their mission is murder and their history is bloody. In recent years, they killed American, Belgian, and Pakistani peacekeepers in Somalia. They plotted to assassinate the President of Egypt and the Pope. They planned to bomb six United States 747's over the Pacific. They bombed the Egyptian Embassy in Pakistan. They gunned down German tourists in Egypt. ${ }^{55}$

Furthermore, in explaining why military action was necessary, the President noted that "law enforcement and diplomatic tools" to combat terrorism had proven insufficient,

83. Address to the Nation on Military Action Against Terrorist Sites in Afg. and Sudan, 2 PUB. PAPERS 1460, 1460 (Aug. 20, 1998).

84. Remarks on Departure for Washington, DC, from Martha's Vineyard, Mass., supra note 82 , at 1460 .

85. Address to the Nation on Military Action Against Terrorist Sites in Afg. and Sudan, supra note 83 , at $1460-61$. 
and that "when our very national security is challenged ... we must take extraordinary steps to protect the safety of our citizens. ${ }^{186}$ Finally, the President made plain that the action of the two targeted countries in harboring terrorists justified the use of military force on their territory: "The United States does not take this action lightly. Afghanistan and Sudan have been warned for years to stop harboring and supporting these terrorist groups. But countries that persistently host terrorists have no right to be safe havens. ${ }^{\prime 87}$

The terrorist incidents of September 11 presented a greater threat to the national security of the United States than the embassy bombings (however appalling those events were). Accordingly, the President's power to respond militarily to those events was broader. Nevertheless, President Clinton's action in 1998 laid the foundation for later unilateral presidential action against terrorism.

First, President Clinton justified the targeting of particular groups on the basis of what he characterized as "convincing" evidence of their involvement in the embassy attacks. While that is not a standard of proof appropriate for a criminal trial, it is appropriate for military and political decision-making. Second, the President targeted not merely one particular group or leader, but a network of affiliated groups. Moreover, he ordered the action, not only because of particular attacks on United States embassies, but because of a pattern of terrorist activity, aimed at both Americans and non-Americans, that had unfolded over several years. Third, the President explained that the military action was designed to deter future terrorist incidents, not only to punish past attacks. Fourth, the President specifically justified military action on the territory of two foreign states because their governments had "harbor[ed]" and "support[ed]" terrorist groups for years, despite warnings from the United States.

\section{The 1993 Strike on Iraq in Respone to the Attempted Assassination of Former President Bush}

On June 26, 1993, President Clinton ordered a Tomahawk cruise missile strike on the Iraqi Intelligence Service (the "IIS")

86. Id. at 1461 .

87. Id. 
headquarters in Baghdad. The IIS had planned an unsuccessful attempt to assassinate former President Bush in Kuwait in April 1993. Two United States Navy surface ships launched a total of 23 missiles against the IIS center.

The President referred to the failed assassination attempt and stated that " $[t]$ he evidence of the Government of Iraq's violence and terrorism demonstrates that Iraq poses a continuing threat to United States nationals. ${ }^{88} \mathrm{He}$ based his authority to order a strike against the Iraqi government's intelligence command center on "[his] constitutional authority with respect to the conduct of foreign relations and as Commander in Chief," in addition to the Nation's inherent right of self-defense. ${ }^{89}$

President Clinton's order was designed in part to deter and prevent future terrorist attacks on the United States, and most particularly future assassination attempts on former President Bush. Although the arrest of sixteen suspects frustrated the assassination attempt, "nothing prevented Iraq from directing a second-possibly successful-attempt on Bush's life. Thus, the possibility of another assassination plot was 'hanging threateningly over [Bush's] head' and was therefore imminent. By attacking the Iraqi Intelligence Service, the United States hoped to prevent and deter future attempts to kill President Bush."90

\section{The 1986 Strike on Libya}

On April 14, 1986, President Reagan, acting on his independent authority, ordered United States armed forces to engage in military action against the government of Colonel Gaddafi of Libya. ${ }^{91}$ Thirty-two American aircraft attacked selected targets at Tripoli and Benghazi, Libya. Libyan officials reported thirty-seven people killed and an undetermined number injured. Over sixty tons of ordnance were used during the attack.

88. Letter to Congressional Leaders on the Strike on Iraqi Intelligence Headquarters, 1 PUB. PAPERS 940 (June 28, 1993).

89. Id.

90. Robert F. Teplitz, Taking Assassination Attempts Seriously: Did the United States Violate International Law in Forcefully Responding to the Iraqi Plot to Kill George Bush?, 28 CORNELL INT'L L. J. 569, 610 (1995).

91. See generally Major Wallace F. Warriner, U.S.M.C., The Unilateral Use of Coercion Under International Law: A Legal Analysis of the United States Raid on Libya on April 14, 1986, 37 NAVAL L. REV. 49 (1988); Teplitz, supra note 90, at 583-86. 
The attack was provoked by Libya's notorious support for terrorist groups and organizations, including evidence of direct terrorist attack orders against United States interests. "Under Gaddafi, Libya has declared its support of 'national liberation movements' and has allegedly financed and trained numerous terrorist groups and organizations, including Palestinian radicals, Lebanese leftists, Columbia's M-19 guerrillas, the Irish Republican Army, anti-Turkish Armenians, the Sandinistas in Nicaragua, Muslim rebels in the Philippines, and left-wing extremists in Europe and Japan." ${ }^{12}$ It had harbored a variety of terrorists, including $\mathrm{Abu} \mathrm{Nidal}$ and the three surviving members of the Black September group that had killed eleven Israeli athletes at the 1972 Munich Olympic Games. ${ }^{93}$ Libya's attacks on the United States included the murder of two United States diplomats in Khartoum (1973), the attempted assassination of Secretary of State Kissinger (1973), the burning of the United States embassy in Tripoli (1979), the planned assassination of President Reagan, Secretary of State Haig, Secretary of Defense Weinberger, and Ambassador to Italy Robb (1981), and the hijacking of T.W.A. Flight 847 (1985). ${ }^{94}$ Libya had also been linked to terrorist events close to the time of the April 1986 airstrike in which Americans and others had lost their lives. In January 1986, American intelligence tied Libya to the December 27, 1985, bombings at the Rome and Vienna airports in which nineteen people, including five Americans, had died, and one hundred and twelve persons had been injured.

The particular event which triggered the President's military action had occurred on April 5, 1986, when a bomb exploded in the "Labelle," a Berlin discotheque frequented by U.S. military personnel. The blast killed three people (two Americans) and injured two hundred and thirty others (including seventy-nine Americans). Intelligence reports indicated that the bombing was planned and executed under the direct orders of the Libyan Government. The United States Ambassador to the United Nations stated that there was "direct, precise, and irrefutable evidence that Libya bears responsibility" for the

92. Teplitz, supra note 90 , at 583 n.112.

93. Id.

94. Id. at 583 n.113. 
bombing of the discotheque; that the "Labelle" incident was "only the latest in an ongoing pattern of attacks" by Libya against the United States and its allies; and that the United States had made "repeated and protracted efforts to deter Libya from its ongoing attacks," including "quiet diplomacy, public condemnation, economic sanctions, and demonstrations of military force."

Like the two unilateral presidential actions discussed above, President Reagan's decision to use armed force in a defensive and preventative response to a terrorist attack on United States military personnel illustrates that President George W. Bush had independent constitutional authority to use such force in the present circumstances.

\section{CONGRESSIONAL ACKNOWLEDGEMENT OF PRESIDENTIAL AUTHORITY}

Our analysis to this point has surveyed the views and practice of the executive and judicial branches. Congress has also addressed the scope of the President's independent constitutional authority in two enactments, the War Powers Resolution and the recent Joint Resolution. These two statutes demonstrate Congress's acceptance of the President's unilateral war powers in an emergency situation, such as that created by the September 11 incidents. Moreover, the President was acting at the apogee of his powers when he deployed military force in the present situation, for he was operating both under his own Article II authority and with the legislative support of Congress. Under the analysis outlined by Justice Jackson in Youngstown Sheet \& Tube Co., (and later followed and interpreted by the Court in Dames \& Moore), the President's power in this case was "at its maximum," because the President was acting pursuant to an express congressional authorization. He was thus clothed with "all [authority] that he possesses in his own right plus all that Congress can delegate, ${ }^{\prime 97}$ in addition to his own broad powers in foreign affairs under Article II of the Constitution. While we do not

95. U.N. SCOR, 41st Sess., 2674th mtg. at 16-17, U.N. Doc. S/PV.2674 (prov. ed. 1986).

96. Youngstown Sheet \& Tube Co. v. Sawyer, 343 U.S. 579, 635 (1952) Jackson, J., concurring in judgment).

97. Id. 
believe that Justice Jackson's approach in Youngstown accurately captures the separation of powers, some scholars do.

\section{A. The War Powers Resolution}

\section{Section 2(c) of the WPR reads as follows:}

The constitutional powers of the President as Commanderin-Chief to introduce United States Armed Forces into hostilities, or into situations where imminent involvement in hostilities is clearly indicated by the circumstances, are exercised only pursuant to (1) a declaration of war, (2) specific statutory authorization, or (3) a national emergency created by attack upon the United States, its territories or possessions, or its armed forces. ${ }^{98}$

The executive branch consistently "has taken the position from the very beginning that section 2(c) of the WPR does not constitute a legally binding definition of Presidential authority to deploy our armed forces." 99 Moreover, as OLC has noted, "even the defenders of the WPR concede that this declaration, found in the 'Purpose and Policy' section of the WPR, either is incomplete or is not meant to be binding." 100 Nonetheless, section 2(c)(3) correctly identifies one, but by no means the only, presidential authority to deploy military forces into hostilities. ${ }^{101}$ In the present emergency, the statute signifies Congress's recognition that the President's constitutional authority alone enabled him to take military measures to combat the organizations or groups responsible for the September 11 incidents, together with any governments that

98. 50 U.S.C. $\$ 1541$ (c) (1994) (emphasis added).

99. Overview of the War Powers Resolution, 8 Op. Off. Legal Counsel 271, 274 (1984). Thus, the State Department took the view, in a letter of November 30, 1974, that section 2(c) was a "declaratory statement of policy." Id. Further, in 1975, the Legal Adviser to the State Department listed six (non-exclusive) situations, not enumerated in section 2(c), in which the President had independent constitutional authority to deploy troops without either a declaration of war or specific statutory authorization. Id. at 274-75.

100. Deployment of U.S. Armed Forces into Haiti, 18 Op. Off. Legal Counsel 173, 176 (1994). See also Presidential Powers Relating to the Situation in Iran, 4A Op. Off. Legal Counsel 115, 121 (1980) ("[T] he Resolution's policy statement is not a comprehensive or binding formulation of the President's powers as Commander-in-Chief.").

101. We note that section 2(c) cannot itself qualify as a statutory authorization to act in national emergencies. It is rather a congressional acknowledgment of the President's nonstatutory, Article II-based powers. Section 8(d)(2) of the WPR, 50 U.S.C. \$ 1547(d)(2) (1994), specifically provides that nothing in the WPR "shall be construed as granting any authority to the President... which authority he would not have had in the absence of this [joint resolution]." 
may have harbored or supported them.

Section 2(c)(3) also does not disturb the President's constitutional authority to determine when a "national emergency" arising out of an "attack against the United States" exists, or the types and levels of force that are necessary or appropriate to respond to that "emergency." Because the statute itself supplies no definition of these terms, their interpretation must depend on long-standing constitutional practice and understanding. As we have shown in Parts I-III of this Article, constitutional text, structure, and practice demonstrate that the President is vested with the plenary power to use military force, especially in the case of a direct attack on the United States. Section 2(c)(3) recognizes the President's broad authority and discretion in this area.

Given the President's constitutional powers to respond to national emergencies caused by attacks on the United States, and given also that WPR section 2(c)(3) does not attempt to define those powers, we think that provision must be construed simply as a recognition of the President's preexisting constitutional authority. Moreover, as we read the WPR, action taken by the President pursuant to the constitutional authority recognized in section 2(c)(3) cannot be subject to the substantive requirements of the WPR, particularly the inter-related reporting requirements in section $4^{102}$ and the "cut off" provisions of section $5 .^{103}$ Insofar as the Constitution vests the power in the President to take military action in the emergency circumstances described by section 2(c)(3), we do not think it can be restricted by Congress through, e.g., a requirement that the President either obtain congressional authorization for the action within a specific time frame, or else discontinue the action. Were this not so, the President could find himself unable to respond to an emergency that outlasted a statutory cut-off, merely because

102. 50 U.S.C. $\$ 1543$ (1994).

103. 50 U.S.C. $\$ 1544$ (1994). True, the reporting requirement in section 4(a)(1), 50 U.S.C. \& 1543(a)(1), purports to apply to any case in which U.S. armed forces are introduced into hostilities "[i]n the absence of a declaration of war." Further, the "cut off" provisions of section 5 are triggered by the report required by section 4(a)(1). 50 U.S.C. $\$ 1544$. Thus, the language of the WPR indicates an intention to reach action taken by the President pursuant to the authority recognized in section 2(c)(3), if no declaration of war has been issued. We think, however, that it would be beyond Congress's power to regulate the President's emergency authority in the manner prescribed by sections $4(a)(1)$ and 5 . 
Congress had failed, for whatever reason, to enact authorizing legislation within that period.

To be sure, some interpreters of the WPR take a broader view of its scope. But on any reasonable interpretation of that statute, it must reflect an explicit understanding, shared by both the Executive and Congress, that the President may take some military actions-including involvement in hostilities-in response to emergencies caused by attacks on the United States. Thus, while there might be room for disagreement about the scope and duration of the President's emergency powers, there can be no reasonable doubt as to their existence.

\section{B. The Joint Resolution of September 14, 2001}

Whatever view one may take of the meaning of WPR section 2(c)(3), it is clear that Congress, in enacting the "Joint Resolution [ $t$ ]o authorize the use of United States Armed Forces against those responsible for the recent attacks launched against the United States"104 ("S.J. Res. 23"), has confirmed that the President had broad constitutional authority to respond, by military means or otherwise, to the incidents of September 11.

First, the findings in the Joint Resolution include an express statement that "the President has authority under the Constitution to take action to deter and prevent acts of international terrorism against the United States. ${ }^{105}$ This authority is in addition to the President's authority to respond to past acts of terrorism. In including this statement, Congress has provided its explicit agreement with the executive branch's consistent position, as articulated in Parts I-III of this Article, that the President has the plenary power to use force even before an attack upon the United States actually occurs, against targets and using methods of his own choosing.

Second, Congress also found that there is a "threat to the national security and foreign policy of the United States posed by the [] grave acts of violence" on September 11, and that "such acts continue to pose an unusual and extraordinary threat to the national security and foreign policy" of this

104. Joint Resolution to Authorize the Use of United States Armed Forces Against Those Responsible for the Recent Attacks Against the United States, Pub. L. No. 107-40, 115 Stat. 224 (2001).

105. Id., 115 Stat. at 224. 
country. ${ }^{106}$ Insofar as "the President's independent power to act depends upon the gravity of the situation confronting the nation," 107 these findings would support any presidential determination that the September 11 attacks justified the use of military force in response. Further, they would buttress any Presidential determination that the nation is in a state of emergency caused by those attacks. The Constitution confides in the President the authority, independent of any statute, to determine when a "national emergency" caused by an attack on the United States exists. ${ }^{108}$ Nonetheless, congressional concurrence is welcome in making clear that the branches agree on the seriousness of the terrorist threat currently facing the Nation and on the need for a military response.

Third, it should be noted that the Joint Resolution is somewhat narrower than the President's constitutional authority. The Joint Resolution's authorization to use force is limited only to those individuals, groups, or states that planned, authorized, committed, or aided the attacks, and those nations that harbored them. It does not, therefore, reach other terrorist individuals, groups, or states that cannot be determined to have links to the September 11 attacks. Nonetheless, the President's broad constitutional power to use military force to defend the nation, recognized by the Joint Resolution itself, would allow the President to take whatever actions he deemed appropriate to preempt or respond to terrorist threats from new quarters.

\section{CONCLUSION}

In light of the text, plan, and history of the Constitution, its

106. $I d$.

107. Youngstown Sheet \& Tube Co. v. Sawyer, 343 U.S. 579, 662 (1952) (Clark, J., concurring in judgment).

108. See The Prize Cases, 67 U.S. (2 Black) 635, 670 (1865) (whether a state of belligerency justifying a blockade exists is to be decided by the President); Sterling v. Constantin, 287 U.S. 378, 399 (1932) ("By virtue of his duty to 'cause the laws to be faithfully executed', the Executive is appropriately vested with the discretion to determine whether an exigency requiring military aid for that purpose has arisen."); Moyer v. Peabody, 212 U.S. 78, 83 (1909) ("[T]he Governor's declaration that a state of insurrection existed is conclusive of that fact."); Campbell v. Clinton, 203 F.3d 19, 26-27 (2000) (Silberman, J., concurring) (stating that the Court in The Prize Cases "made clear that it would not dispute the President on measures necessary to repel foreign aggression"); $c$. Martin v. Mott, 25 U.S. (12 Wheat.) 19, 30 (1827) (stating that the President had unreviewable discretion to determine when "emergency" existed under statute enabling him to call up militia). 
interpretation by both past administrations and the courts, the long-standing practice of the executive branch, and the express affirmation of the President's constitutional authorities by Congress, it is clear that the President had the plenary constitutional power to take such military actions as he deemed necessary and appropriate to respond to the terrorist attacks upon the United States on September 11, 2001. Further, the President had the authority to use force both to retaliate for those attacks and to prevent and deter future assaults on the nation. Military actions need not be limited to the particular individuals, groups, or states that participated in the attacks on the World Trade Center and the Pentagon. The Constitution vests the President with the power to strike terrorist groups or organizations that cannot be demonstrably linked to the September 11 attacks, but who, nonetheless, pose a similar threat to the security of the United States and the lives of its people, whether at home or overseas. ${ }^{109}$ In both the War Powers Resolution and S.J. Res. 23, Congress recognized the President's authority to use force in circumstances such as those created by the September 11 incidents. Neither statute, however, could place any limits on the President's determinations as to any other terrorist threat, the amount of military force to be used in response, or the method, timing, and nature of the response. Those decisions, under our Constitution, are for the President alone to make.

109. We of course understand that terrorist organizations and their state sponsors operate by secrecy and concealment, and that it is correspondingly difficult to establish, by the standard of criminal liability or even lower legal standards, that particular individuals or groups have been or may be implicated in attacks on the United States. Moreover, even when evidence sufficient to establish involvement is available to the President, it may be impossible for him to disclose that evidence without compromising classified methods and sources, and so damaging the security of the United States. See, e.g., Chicago \& S. Air Lines, Inc. v. Waterman Steamship Corp., 333 U.S. 103, 111 (1948) ("The President . . . has available intelligence services whose reports are not and ought not to be published to the world."); see also Ruth Wedgwood, Responding to Terrorism: The Strikes Against Bin Laden, 24 YALE J. INT'L L. 559, 568-74 (1999) (analyzing difficulties of establishing and publicizing evidence of causation of terrorist incidents). But the difficulty or impossibility of establishing proof to a criminal law standard (or of making evidence public) does not bar the President from taking such military measures as, in his best judgment, he thinks necessary or appropriate to defend the United States from terrorist attacks. In the exercise of his plenary power to use military force, the President's decisions are for him alone, and are not subject to judicial review. 
HeinOnline -- 25 Harv. J.L. \& Pub. Pol'y 518 2001-2002 